\title{
Response of soil hydraulic properties to soil macropore characteristics from an opencast coal mining area using a CT scanning method
}

\author{
Zhaorui Jing ${ }^{1}$, Jinman Wang ${ }^{2}$, and Yu Feng ${ }^{1}$ \\ ${ }^{1}$ China University of Geosciences Beijing \\ ${ }^{2}$ Ministry of Natural Resource
}

May 29, 2020

\begin{abstract}
Soil compaction resulted from heavy machineries in opencast coal mine areas alters soil macropore characteristics then affects soil hydraulic properties. Additional information related to hydraulic characteristics is needed to assess the effects of soil reconstruction to improve the soil quality. The aim of this study was to determine the hydraulic properties and macropore characteristics of compacted soil by simulation tests and CT scanning in laboratory and to explore the response of soil hydraulic properties to soil macropore characteristics. In this study, the disturbed soil samples from the dumping area of Pingshuo opencast coal mine of China were collected. The soil samples were processed in designed bulk density (BD) from $1.30 \mathrm{~g} \cdot \mathrm{cm}-3$ to 1.70 $\mathrm{g} \cdot \mathrm{cm}-3$, and the soil hydraulic properties, including soil-water characteristic curve (SWCC), saturated hydraulic conductivity $(\mathrm{Ks})$, soil moisture diffusivity $(\mathrm{D}(\vartheta)$ ), field capacity $(\mathrm{FC})$, wilting coefficient (WC) were measured and the soil macropore characteristics were obtained using CT scanning in laboratory. The path analysis method was applied to analyze the effect of macropore characteristics on soil hydraulic properties. Soil compaction resulted in severe effects on soil hydraulic characteristics and macropore properties. Under same soil suction, the water contents remained in soil decreased with increasing compaction. Soil-water holding capacity, soil saturated hydraulic conductivity, and soil water diffusivity decreased with increasing BD. The explanatory variables (average euler number (AEN), macropore throat number (PTN), and macropore fractal dimension (PFD)) were main determinants of soil-water holding capacity, and the indirect path coefficient of macroporosity. The effects of average euler number (AEN) and macropore fractal dimension (PFD) on soil infiltration properties were relatively high. The BD of 1.4 $\mathrm{g} \cdot \mathrm{cm}-3$ was a critical point of affecting macropore properties then affecting soil hydraulic properties, and some soil reclamation measures should be conducted to make $\mathrm{BD}<1.4 \mathrm{~g} \cdot \mathrm{cm}-3$ for compacted soil in opencast coal mining area. This study provides valuable data for soil restoration of soil hydraulic and macropore properties in mining areas.
\end{abstract}

\section{Hosted file}

Manuscript.doc available at https://authorea.com/users/327762/articles/455209-responseof-soil-hydraulic-properties-to-soil-macropore-characteristics-from-an-opencast-coalmining-area-using-a-ct-scanning-method

\section{Hosted file}

Figure.doc available at https://authorea.com/users/327762/articles/455209-response-of-soilhydraulic-properties-to-soil-macropore-characteristics-from-an-opencast-coal-miningarea-using-a-ct-scanning-method

\section{Hosted file}

Table.doc available at https://authorea.com/users/327762/articles/455209-response-of-soil- 
hydraulic-properties-to-soil-macropore-characteristics-from-an-opencast-coal-miningarea-using-a-ct-scanning-method 